\title{
The Presence of the Ascended Son in the Gospel of John
}

\author{
Markus Bockmuehl, University of Oxford
}

The Fourth Gospel distinctively articulates the shared Christian conviction that Jesus of Nazareth rose from the dead after his crucifixion and was exalted to heaven. ${ }^{1}$ As for other New Testament writings, that belief also raises the fundamental question of how this same Jesus continues to relate to ongoing Christian faith and experience. Where is Jesus now? Is he here or somewhere else, at a spatial and perhaps temporal remove from the lives his followers lead now?

That rather basic question is made strange and complex as soon as one begins to reflect on its methodological elusiveness. In scholarly and critical study of the gospels our question is further complicated by its methodological elusiveness. There are many possible ways to try and contextualize it in either ancient cultural or modern analytical settings. A century ago, standard approaches to the comparative study of ancient religion tended to focus on expressions of divine presence either in terms of 'the numinous' (R. Otto), ${ }^{2}$ of social ritual as expressing the power of society (E. Durkheim), or in history-of-religions comparisons with providential or animistic conceptions. Today the comparative bird's eye view has for the most part surrendered to more focused textual and empirical study of the texts and phenomena in view. So, for example, one frame of reference might be Jewish, early Christian and Graeco-Roman mysticism, on which a good deal of work has been done in recent years. Others have studied the role of interiority and cognitivity in specific religious traditions. There have been books on ascetical, shamanistic and neurobiological aspects of ecstatic experience, especially in relation to the Apostle Paul. And a series of recent studies has called for fuller discussion of the role of religious experience in the formation of early

\footnotetext{
${ }^{1}$ I am grateful for questions and comments from Anthony Giambrone, Greg Tatum and other conference participants. Parts of this material were previously presented as part of the 2018 Didsbury lectures in Manchester, which I hope in turn to publish as part of a larger monograph (ca. 2021). I also wish to acknowledge valuable feedback and suggestions from the Didsbury audience as well as from Marianne Meye Thompson.

${ }^{2}$ E.g. Otto 1923, 85: 'In the Gospel of Jesus we see the consummation of that process tending to rationalize, moralize, and humanize the idea of God, which began with the earliest period of the old Hebrew tradition and became specially prominent as a living factor in the Prophets and the Psalms, continually bringing the apprehension of the numinous to a richer fulfilment by recognizing in it attributes of clear and profound value for the [sic] reason. The result was the faith in ' the fatherhood of God ' in that unsurpassable form in which it is peculiar to Christianity.'
} 
Christian belief and theology. The broader theme of divine presence and absence has also repeatedly attracted the attention of scholarship on ancient Israel and Second Temple Judaism.

A clearer methodological account must be left for another occasion. I do not doubt that many of these modes of characterizing divine presence are relevant to a description of early Christian realities: quite likely they are. This paper probes the focused and in a sense 'dogmatic' question about how the Gospel of John envisages the location of Jesus after his earthly lifetime. How does the Fourth Evangelist handle the dialectic between affirmations that Jesus is present with the disciples or on the other hand that he has gone to another place? I am for present purposes less concerned with abstract definitions of absence or presence in metaphysical or personalist terms, ${ }^{3}$ nor with a comparative phenomenology of Johannine religious experience. Instead, my focus will be on the Gospel of John's stated ('emic') affirmations about the presence or the absence of the post-Easter Jesus - i.e. the convictions that shaped and were in turn shaped by this evangelist and his community.

The Fourth Gospel's manuscript distribution and especially its reception in the exegetical disputes and deliberations leading up to the great Christian creeds leave no doubt that this text had an inestimable effect on the formulation of Christian doctrine about the person of Jesus Christ. Among the company it keeps in the library of early Christian sacred texts, the Gospels of Matthew, Mark and Luke are clearly paramount. Richard Bauckham and others have plausibly argued for John's knowledge of something rather like the gospel of Mark in particular; and despite some useful criticisms that view may represent a growing consensus. ${ }^{4}$ But beyond this there has long been a notable trickle of New Testament scholarship which would affirm the historical priority of John over the Synoptics, ${ }^{5}$ or even just over Luke. ${ }^{6}$ Others more cautiously propose stages of composition in which each stream of gospel tradition influenced the other, possibly through the continuing interrelationship between writing and primary or secondary oral tradition. ${ }^{7}$

But rather more revealing than this gospel's inscrutable literary relationships with other New Testament texts is its formative influence on early Christian belief. One thinks here of the Prologue's

\footnotetext{
${ }^{3}$ For an attempt at the former see e.g. Slenczka 1993; for the latter see e.g. Walsh 2015.

${ }^{4}$ See e.g. Bauckham 1998, 2007 passim.

${ }^{5}$ So most famously Robinson 1985; cf. also Berger 1997.

${ }^{6}$ So e.g. Boismard 2001; Shellard 2002; Matson 2001, 2004. Nielsen 2018 offers a history of research on this relationship (134-39) and concludes in favour of Luke's priority over John.

${ }^{7}$ For the history of this question of relative priority see e.g. Hofrichter 2002; Matson 2004; Nielsen 2018, 126-34.
} 
exegetical pressure on the Creedal language of Jesus as the only-begotten Son co-eternal with the Father: 'God from God, Light from Light, true God from true God, begotten, not made, consubstantial with the Father; through him all things were made.' The influence of John's Gospel is unmistakable, and was explicitly recognized in the ancient debates that generated these formulations. It is vital to see that 'Christian Scripture does not yield a normative theology but suggests a doctrinal norm' - and it can be an appropriately critical judgment to conclude that no New Testament text has a better approximation to this doctrinal norm than the Gospel of John. ${ }^{8}$

One might say that in Matthew, Mark and Luke the story invites its readers into a growing appreciation of who Jesus is as the account unfolds. The narrative build-up of Jesus happens in a more linear fashion, even if the whole invariably turns out to be much greater than the parts. And to be sure, on returning to the beginning from the end, those Synoptic parts do turn out in fact to be replete with the whole.

In the Gospel of John, by contrast, that linearity of disclosure and understanding becomes rather more complicated. This is because John's Prologue dramatically front-loads the question of Christology from the very first line of the text. The divine identity of Jesus Christ is fully and explicitly in focus from the start. So the effect here becomes less cumulative: as readers seek to understand what Jesus says and does, it seems that each part of the story is already full to bursting with the whole.

The whole of Jesus as the coeternal Son invades the narrative from the start. But this also inevitably colours the central question of this study: for the Fourth Evangelist, where is this Logos now - risen in his flesh $(20.20,27)$ but no longer bodily manifest in his earthly life? Is he still present to believers here, revealing his glory and empowering them to become the children of God (1.12, $14)$ ? Or is he absent to them, somewhere else?

The Fourth Gospel engages more articulately and acutely than the Synoptics with the tension between the present and the absent post-Easter Jesus. On one account nearly half of this gospel is concerned with the topic of Jesus' death and departure. ${ }^{9}$ This theme of departure and bereavement dominates from chapter 13 onwards, but there are numerous references to it well before then, raising important questions about the presence and absence of Jesus long before the passion narrative.

\footnotetext{
${ }^{8}$ Cf. Morgan 1996, 207, 217-23 (ital. mine).

${ }^{9}$ Thus Eckstein 2011, 162 with reference to 13.1-20.31/21.25.
} 
My approach here will foreground attention to explicit statements relating to the post-Easter Jesus, and where possible to avoid the temptation to appropriate narrative motifs allegorically with little or no warrant in the text. ${ }^{10}$

\section{The Public Ministry ('Book of Signs', 1-12)}

I begin with the public ministry of Jesus in the first 12 chapters, sometimes called the 'Book of Signs', before turning to the Farewell Discourses and the passion and resurrection accounts in the second half of the Gospel (the so-called 'Book of Glory', 13-21).

\section{The Incarnation of the Eternal Word (1)}

As already intimated, the Prologue's sustained and powerful language of the incarnation clearly foregrounds the Word's presence to the Father and then to his own people in coming into the world. He enters as the light into darkness, becoming flesh and dwelling among us (1.1-14). As God the only Son, the Logos uniquely made known ( $\dot{\xi \eta \eta \eta ́ \sigma \alpha \tau o, 1.18) ~ t h e ~ i n v i s i b l e ~ G o d ~ t h e ~ F a t h e r ~ t h r o u g h ~ h i s ~}$ incarnation. These rightly celebrated lines are impossible to overestimate in their influence on the formation and articulation of Christian faith through the centuries.

Significantly for my purposes, however, the verbal tenses deployed in the Prologue have their reference almost exclusively in the incarnational past. The only exceptions relate to the Evangelist's light imagery and to the Son's timeless presence to God: key phrases are 'the light shines ( $\varphi \alpha$ Ível) in the darkness' (1.5), 'the true light which enlightens ( $\varphi \omega \tau i ́ \zeta \varepsilon \iota)$ everyone' (1.9), and 'God the only

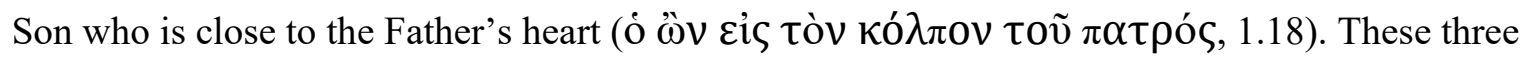
expressions evidently evoke certain aspects of timelessness in how Jesus is present to the narrative and by implication to the believing reader. Particularly striking potential in this respect may additionally lie in the evangelist's assurance that to 'all who received him' and 'believed in his name', he who is Word and True Light gave 'the power ( $\dot{\xi}$ ou $\sigma i \alpha)$ to become children of God' (1.12). Hints at a timeless presence occasionally surface in the Synoptics, too, perhaps especially in Matthew. But in John they are much more frequent; and as we shall see, they continually raise questions about where Jesus is located when he utters them or they are uttered about him.

\footnotetext{
${ }^{10}$ The latter remains a widespread tendency. Carson 1991, 274-75 on 6.16-18 offers just one of numerous examples: 'The words By now it was dark, and Jesus had not yet joined them, though doubtless prosaically true, may also be symbolladen: as in 3:2; 13:30, the darkness of night and the absence of Jesus are powerfully linked.' While doubtless generally true to Johannine sentiments this conclusion is here unsupported by any evident textual warrant.
} 
That said, the Son's past incarnation in the earthly life of Jesus is clearly John's primary narrative interest and starting point, even if his stories invariably and deliberately carry a surplus of meaning that signifies far more than they appear to say at face value.

The Prologue's culminating emphasis on the Word becoming flesh also encourages a reading of the gospel narrative in terms of its focus on the visible, tangible presence of that incarnate Word: 'we have seen his glory' (1.14). It is 'upon' him as the heavenly Son that the very angels will 'ascend and descend', just as in Jacob's dream they did 'upon' the ladder linking heaven and earth. And as soon as the narrative gets underway, we find that through his signs Jesus 'revealed his glory, and his disciples believed in him' (2.11).

It is true that this visibility of the earthly Jesus is of course shared with the other gospels. But John does seem to make a particular feature of it. One of the Fourth Gospel's favourite verbs for the process of coming to faith in Jesus Christ is 'seeing'. Examples include Jesus inviting two disciples of John to 'come and see' (1.39), or the Samaritan woman calling her neighbours to faith: 'Come and see a man who told me everything I have ever done! He cannot be the Messiah, can he?' (John 4:29; cf. 42). A few chapters later, the man born blind replies to a challenge about Jesus with an exquisitely ironic confession: 'I do not know whether he is a sinner. One thing I do know, that though I was blind, now I see' (John 9:25).

Seeing that presence of Jesus is for John not only a central image of faith, but it is also at the very heart of Jesus' ministry. It is the reason why he has come (John 9:39): 'I came into this world for judgement so that those who do not see may see, and those who do see may become blind.' And he insists that seeing and knowing the Son is also to see and know the Father (12.45; cf. 14.7). ${ }^{11}$ The Catholic philosopher Romano Guardini rightly called the Fourth Evangelist a 'man of the eye'. ${ }^{12}$

It is not perhaps immediately clear quite how much this theme of seeing contributes to our question of Jesus's presence or absence after Easter. Indeed, John later has the post-resurrection Jesus strongly relativize the importance of sight in favour of those who believe without having seen (20.29) - a point that more than one commentator emphatically relates to the theme of his absence. ${ }^{13}$ Nevertheless, it matters to the Fourth Evangelist that the presence of the incarnate Word to the eyes of the apostolic witnesses also grants valid access to the presence, life and metaphorical sight of

\footnotetext{
${ }^{11}$ Frey 2016 develops this theme more fully throughout.

${ }^{12}$ Guardini $1962,53,57 *^{*}$ Cf. the more philosophical exploration of this theme of the 'phenomenology of Christ' in Michel Henry 2003, 69-93 and passim.

${ }^{13}$ See e.g. Moloney 1998, 163, 178-79.
} 
Jesus for those who believe on the basis of the apostolic testimony (cf. 19.35; 20.30-31). Past apostolic sight of Jesus undergirds the present insight of faith, and it invalidates the option of a merely docetic, symbolic presence. ${ }^{14}$

\section{The Descended and Ascended Son: Jesus and Nicodemus (3)}

Illustrations of the timeless simultaneity of Jesus's earthly and heavenly presence feature repeatedly even in the early chapters. So Jesus says to Nicodemus, 'No one has ascended into heaven except the one who descended from heaven, the Son of Man. ${ }^{15}$ And just as Moses lifted up the serpent in the wilderness, so must the Son of Man be lifted up, that whoever believes in him may have eternal life' (3.13-15). While the forward-looking reference to the Son of Man's 'lifting up' bringing eternal life makes good sense at this point of the narrative, what is striking is that John's otherwise familiar and intelligible dynamic of the Son's descending and ascending (cf. 3.31; 6.33, 38, 42, 51, 58, 62; 7.34; $8.23 ; 16.28 ; 20.17)$ here again leaves uncertain the question of the vantage point. The language of the Son's 'descent' from heaven and subsequent ascent is of course frequent throughout the text. As late as 20.17 after the resurrection we hear the Jesus has 'not yet ascended to the Father'.

The descent and re-ascent of heavenly figures is as such a familiar trope from pre-Christian Jewish sources, although not perhaps as closely related to the ascent (and eschatological descent) of prophets like Moses or Elijah as commentators sometimes assert. ${ }^{16}$ In addition to the influential angels on Jacob's ladder whom we encountered earlier (1.51; cf. Gen 28.12), the theme is comparably used of the Logos of God in the book of Wisdom (18.14-16) or of the Messiah in a number of other texts. ${ }^{17}$ And while the Synoptic evangelists may make little explicit use of it, it is already clearly present in earlier Pauline texts like the letter to the Philippians (Phil 2.6-8).

And yet here it seems as if that ascension has already happened, so that at least for the reader the Jesus of chapter 3 already reflects the default state of post-Easter absence with which so much of the second half of the Gospel is concerned: the only one who has (already?) ascended into heaven is the Son of Man, who descended from heaven. A comparable passage appears in 7.34, where Jesus

\footnotetext{
${ }^{14}$ The Docetic interpretation famously associated with Wayne Meeks 1972 and Ernst Käsemann 1969 has been abandoned by most interpreters (see e.g. Schnelle 1992; Thompson 1988), although it periodically resurfaces (e.g. Kobel 2011, 301-16).

${ }^{15}$ The majority of the manuscript tradition reads, 'the Son of Man who is in heaven' - a reading that merits discussion as potentially preferable: cf. Metzger 1994, 174-75.

${ }^{16}$ See also the ambitious argument of Gathercole 2006, 137-41 and passim attempting to make the same case for the Synoptics.

${ }^{17}$ Sib Or 5.414; 4 Ezra 12.32; 14.52; 1 Enoch 39.6f.; 46.1-4.
} 
anticipates his return to the Father and warns his uncomprehending opponents that 'You will search for me, but you will not find me; and where I am, you cannot come.' (Note the striking present tense

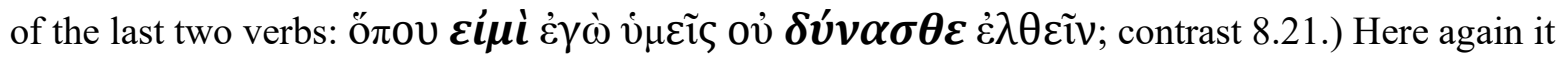
seems as if Jesus is absent as the already-ascended one, who elsewhere identifies himself as 'not of this world' and 'from above' (8.23).

\section{The Bread of Life (6)}

Among the pre-Easter teachings of the Johannine Jesus, the Eucharistic connotations of the Bread of Life discourse in chapter 6 have always been a central locus of critical and theological debate. Jesus famously offers no words of institution or interpretation over the last meal with his disciples in chapter 13, which unlike the Synoptics John does not characterize as a Passover meal. Instead, a strongly sacramental-sounding interpretation attaches to Jesus's instruction after the feeding of the 5000 (6.35-58). He identifies himself in apparently timeless terms as the 'bread of life', offering the universal assurance that 'whoever comes to me will never be hungry, and whoever believes in me will never be thirsty' (6.35).

As this is reiterated and expanded at the end of the discourse, it seems at first to be tethered more narrowly to the incarnation: Jesus is 'the living bread that came down from heaven', specifically to give his flesh for the life of the world (6.51). But its application then expands more boldly to a set of affirmations that seem to locate in Jesus's flesh and blood an abiding presence that is in principle both available and necessary for all believers, whether during or after the earthly ministry:

Very truly, I tell you, unless you eat the flesh of the Son of Man and drink his blood, you have no life in you. Those who eat my flesh and drink my blood have eternal life, and I will raise them up on the last day; ... Those who eat my flesh and drink my blood abide in me, and $I$ in them. ... The one who eats this bread will live forever (6.53-58)

The Johannine Jesus here speaks with confidence about his presence to the believer from now until the 'last day', suggesting that the assurances here given are not restricted to the time of his earthly ministry. Such 'ingestion' of the Son of Man, it seems, secures the permanent benefit of his presence to each participating believer.

Whether this promise is for the evangelist therefore specifically and explicitly located in the Eucharist and the Eucharistic elements is another matter. It is at any rate not hard to find commentators who favour such a reading; many do so very emphatically. ${ }^{18}$ While all other clear

\footnotetext{
${ }^{18}$ E.g. Brown 1966-70, 1:258.
} 
references to the Eucharist in Paul and the Gospels do connect it unambiguously to the Last Supper, this connotation is not present in John 6. It does seem in some respects attractively neat and compelling, even if less than wholly self-evident. A specific Eucharistic context may be difficult to prove beyond doubt in John 6 . Nevertheless, the text as it stands certainly underscores at a minimum that the condition for resurrection life and the Son's indwelling presence is to accept and receive Jesus as God's true food from heaven in his incarnate entirety, in his person and his words.

That said, as soon as the Eucharist became integral to the Christian celebration of Jesus, this text very quickly engendered a Eucharistic association that spoke of the powerfully effective presence of Jesus to the believer in corporate worship. In fact, it appears that this connection may have been made virtually as soon as the ink was dry on the Fourth Evangelist's papyrus: thus Ignatius of Antioch already speaks of the church's breaking bread together as 'the medicine of immortality, the antidote that we should not die, but live for ever in Jesus Christ' (Ign. Eph. 20.2; cf. Rom. 7.3). ${ }^{19}$

\section{The Present 'I Am'}

This consideration of John 6 raises the question of the so-called 'I Am' sayings more generally, which have rightly attracted a large amount of scholarly attention. ${ }^{20}$ What are we to make of Jesus's statements that 'I am the bread of life' $(6.35,41,48,51)$, 'I am the Light of the world' $(8.12 ; 9.5)$, 'I am the gate' (10.9), 'I am the Good Shepherd' (10.11), 'I am the resurrection and the life' (11.25), 'I am the Way, the Truth and the Life' (14.6), and 'I am the true vine' (15.1)? Are they intended underscore the connection of his continuing presence as bread, light, gate, Shepherd, etc.?

Much Johannine scholarship has regarded these sayings as programmatic and definitive for the Christology of the Fourth Gospel, often claiming that these sayings are specifically and deliberately seven in number. ${ }^{21}$ This popular claim requires one to ignore the repetitions and

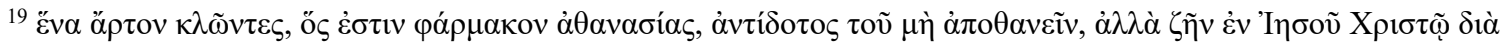
$\pi \alpha v \tau$ ós. This link, which finds regular acknowledgement in later patristic writers (see e.g. documentation in Elowsky 2006-07, 1:227), is also supported by Popkes 2017, 511 ('Bereits bei Ignatius von Antiochia lässt sich erkennen, inwieweit in Rekurs auf die johanneische Lebensbrotrede das Motiv der Gegenwart Jesu im eucharistischen Geschehen begründet werden konnte.')

${ }^{20}$ For recent treatments and discussion of prior scholarship see e.g. Anderson 2011; Förster 2017; Petersen 2008; Rusam 2005 and previously Williams 2000; also cf. Facius 2016.

${ }^{21}$ But cf. more cautiously Witherington 1995, 156; Culpepper 1999, 81-85.
} 
variations of several sayings (esp. 'bread of life' and 'light of the world'); it also raises difficulties around the striking statement 8.58 that 'before Abraham was, I am'.

Leaving aside this somewhat sterile numerical problem, it is undoubtedly the case that these are timeless statements about Jesus's identity, whose relevance does seem to extend beyond his lifetime and therefore into the Evangelist's present day. Recent scholarship has increasingly shown that these sayings at the heart of John's Christology plausibly derive from core Synoptic convictions that are then developed and expounded in the associated Johannine discourses. ${ }^{22}$

But the question at issue here is about where John envisages Jesus to be after Easter, whether that be described in physical, relational or metaphorical conceptions of space. While the 'I Am' sayings do of course offer a timeless account of who Jesus is, and to some extent what he does, they are markedly less clear about where he is in relation to the believer.

It is in principle possible that all the 'I Am' statements are intended to describe a timeless and permanent presence of Jesus to the evangelist's here and now. But that would make for a rather attenuated sense of 'presence' - and close reading seems in several cases to make this difficult to sustain in the text. At 9.5, for example, we encounter the temporally bounded affirmation, 'as long as I am in the world, I am the light of the world'. Similarly, it is worth asking whether there is some necessary disruption to the Good Shepherd's work as he lays down his life for the sheep (10.11), not least since after Easter we find him entrusting his Shepherding task to Simon Peter (21.15-17).

In short: the 'I Am' sayings yield less explicit information about our specific question of presence and absence than might at first appear to be the case. A similar conclusion probably follows for several related Christological statements that also seem to have a timeless application. One thinks here for example of relational claims like 'the Father and I are one' or 'the Father is in me and I am in the Father' $(10.30,38)$, neither of which seems particularly eloquent on his where he is now.

\section{Lazarus and the Absence of Jesus (11)}

A more promising and widely discussed passage in relation to our question is the story of Lazarus in chapter 11. This is in many ways pivotal to the structure of the whole gospel. It attracts one of the longest narratives about a miracle, dwells extensively on death and resurrection, and in one view

\footnotetext{
${ }^{22}$ So e.g. Anderson 2011.
} 
almost appears to take the place of the otherwise absent exorcism narratives of the synoptic gospels. $^{23}$

The central concern of this passage is patently about Jesus's messianic power to defeat death and to raise the dead, which is a traditional Jewish eschatological affirmation both about God (for example in the daily Amidah prayer ${ }^{24}$ ) and about God's Messiah (for example at Qumran). ${ }^{25}$

At the same time, Wendy North has argued that a subsidiary theme in the passage is how to deal with the problem of the absence of Jesus and perhaps his failure to return. ${ }^{26}$ This problem does arguably surface in the Farewell discourses, as we will see. But North regards the absence of Jesus as a painful and pressing concern to John's readership throughout: it is 'the situation that informs the Gospel at every turn' (41), whose flames are fanned by persecution, and whose effect she sees attested in chapter 17 as threatening the very breakup of the Johannine community. It is this that also shapes her reading of chapter 11 in particular. She finds its meaning encapsulated in Jesus's somewhat puzzling delay before arriving in Bethany, evoking Mary's counterfactual, disappointed statement that, 'Lord, if only you had been here, my brother would not have died' (11.21). In response to this, she finds John drawing comfort for his audience from the promise of resurrection life and from resorting to the Holy Spirit as the substitute for the absent Jesus.

The story of Lazarus clearly held enormous resonance for early Christian readers of John, as it provided them with a graphic image of striking humanity to give hope in Jesus as the Lord of life and death. Beginning with some of the earliest expressions of Christian art, Lazarus held pride of place not least on the occasion of Christian funerals and burials. Charles Hill's influential study of John's impact in the early church notes the frequent paintings of Lazarus in the catacombs. ${ }^{27}$ The theme of his second death and burial took hold several centuries later at Kition (modern Larnaca) in Cyprus, which claimed him as its first bishop.

\footnotetext{
${ }^{23}$ So e.g. Lindars 1992.

${ }^{24}$ Amidah petition 2: 'blessed are you, LORD who raises the dead to life' ברוך אתה "י מחיה המתים

25 4Q521: 2.ii.12 '[for] he will heal the badly wounded and will make the dead live, he will proclaim good news to the poor' ירפא חללים ומתים יחיה ענוים יבשר].

${ }^{26}$ North 2013.

${ }^{27}$ Hill 2004, 156-57, also quoted by North 2013, 50.
} 
Jesus's unexplained delay and Mary's heartfelt sadness at his absence during her moment of need are doubtless a feature of this story, and commentators rightly note their pastoral significance. ${ }^{28}$ But these features do not dominate the narrative in the way that North asserts. The absence of Jesus is temporary, thoughtful and deliberate; and it evidently results in deliverance for Lazarus and his sisters. Mary recognizes as much when she immediately goes on to temper her disappointment with an unreserved expression of trust: 'Even now I know that God will give you whatever you ask of him' (11.22). Read in that light, v. 21 is not reproachful but functions, despite the note of disappointment, as a statement of fact and of trust: the presence of Jesus would have had the effect of

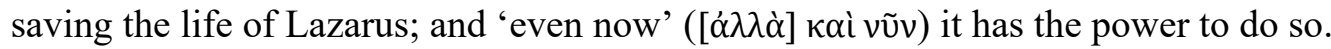

There is little sign here of desperation, let alone of a community about to break under the strain of Jesus's absence. Explicit reproach about that absence, such as it is, comes neither from Mary or her friends but rather from the group identified as 'the Jews', some of whom are heard wondering, 'Could not he who opened the eyes of the blind man have kept this man from dying?' (11.37). Faced with the raising of Lazarus, however, even that reproach appears to turn to faith: 'many of the Jews... believed in him' (11.45). What is more, even the chief priests plotting his death detect in the report of these events not a problem of absence but only the danger that 'If we let him go on like this (oú $\tau \omega \varsigma)$, everyone will believe in him' (11.48).

All in all, therefore, John 11 hardly reads well as a story problematizing an absent post-Easter Jesus. Instead, it manifests to the believers of Bethany an anticipation of the life-giving eschatological presence of the Son. ${ }^{29}$

\section{The Farewell Discourses and the Passion (13-19)}

Throughout the story of the earthly ministry, John repeatedly focuses the significance and purpose of Jesus' life more specifically on his impending 'hour', which in the first half of the gospel 'has not yet come' $(2.4 ; 7.30 ; 8.20)$ until at the beginning of the passion narrative we finally discover that in fact now it 'has come' $(12.23,27 ; 13.1 ; 17.1)$. In that sense John's narrative positively requires this somewhat more back-loaded sequence, which allows him to animate his understanding of the cross as the hour of Jesus's redemptive 'lifting up' on behalf of his friends.

\footnotetext{
${ }^{28}$ Note e.g. Thompson 2015, 245 who also quotes Koester 2003, 65 on the sister's words resonating with readers 'as they experienced sickness and death in a time when Christ was not visibly present, and as they turned to a seemingly absent Christ for help and received no timely answer.'

${ }^{29}$ Cf. Eckstein 2011, 163-67.
} 
With 12.23 as the first announcement that his hour has now come, the gospel has now reached a crucial turning point as Jesus's departure and absence draws near. Jesus begins to hint at this later in the same chapter in predicting the saving significance of his crucifixion ('when I am lifted up from the earth, I will draw all people to myself' 12.32). And he warns his audience that (his) light will be with them only for a little while longer before darkness overtakes them $(12.35$, anticipated in 9.4). The implication of absence in that darkness is often asserted, but it seems just as feasible to read this darkness as above all of the Triduum, the period between the Cross and the Resurrection: As one commentator puts it,

...The night seems to be the time when Jesus is absent from the world between his death and resurrection, since thereafter the Spirit will be present (20:22) who will continue Jesus' work through the disciples. Through this strong warning, which regards such a limited period of time, we are led to see the enormity of the darkness of those three days in salvation history. ${ }^{30}$

The disciples' experience of the darkness temporarily overtaking the light also needs to be contextualized in relation to 1.5 , where the Evangelist asserts more categorically that the darkness has not finally overcome the light of Christ.

More often than in the other gospels, John's Jesus announces that he has to 'go away'. He does so repeatedly, beginning quite early in the narrative. ${ }^{31}$ Even by chapter 7, this is a point not lost on a quizzical audience wondering if he is going to the Greeks (7.35). It is a distinctive feature of this gospel that Jesus himself quite explicitly tackles the problem of his departure from the disciples while he is still with them, rather than after Easter (as he does in Luke).

The drawn-out reflections of Chapters 13 to 17 accompanying Jesus's final meal with his disciples occupy the chronological space that in the Synoptics is taken up by the much briefer accounts of the Last Supper. Specifically, these Farewell Discourses dwell extensively on the question of presence and communion with Jesus once he is no longer there. It is precisely the fact

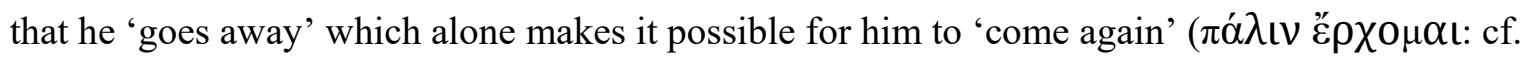
$14.3,18,28)$ in order to take his disciples to the apartments he has prepared for them in his Father's house.

This may seem on the surface a puzzling and disturbing rationale: why inflict on the disciples the bereavement of the interim, just for the sake of being able to return to them?

\footnotetext{
${ }^{30}$ Whitacre 1999, 237-38.

${ }^{31}$ E.g. $7.33 ; 8.14,21-23 ; 13.3,33,36 ; 14.2-3,28 ; 16.5,7,17,19 ; 17.11,13 ;$ cf. 20.17.
} 
An important point to note is that like the other New Testament gospels, John engages the theme of absence as the essential consequence of a temporally bounded incarnation. This also strikingly separates his approach from that of the timeless Saviour of several of the Nag Hammadi Gospels, who never stoops to take flesh and who instead carries his disembodied disclosure exclusively to the elite gnostic mind - a mind whose inner divine spark is raised above merely earthly and human realities. ${ }^{32}$

\section{The Paraclete}

As we saw earlier, a basic theological challenge throughout these discourses is the impending absence of Jesus: how can his person and his salvation possibly be mediated if the incarnation of divine salvation is now absent? Rather than affirming a Matthean idea of continued presence, the Johannine Jesus here stresses his departure over and over (beginning with 13.33-38).

John's solution is similar to Luke's, but developed in considerable depth and complexity. Jesus promises that while he himself will 'go away', Father and Son will send 'another' advocate or ombudsman, the Spirit, who will in fact be 'with' and 'in' the believers forever (14.16-17; 14.25-26; 15.26). The Advocate or Paraclete supplies whatever might be lacking in the presence of Jesus. The problem of departure and absence is packaged in such a way as to allow the Paraclete to overcome the tension as manifesting God's love, mediating his joy and presence to disciples who are thus not left abandoned. ${ }^{33}$

This Johannine promise of 'another' Paraclete famously lent hostages to fortune, which the followers of both Mani (CMC 64.8-65.18) and Mohammed (Qur'an 61.6 and commentaries) put to ready use in their own cause.

That said, John's correlation between Jesus and the Paraclete is so inextricably close that the Paraclete does inalienably manifest the love and living presence of Jesus himself. 'Another' Paraclete appears therefore to mean not 'other' but more of the same: their distinctive unity is the reason Jesus can in these chapters paradoxically claim to be absent without leaving the disciples 'orphaned' (14.18).

\footnotetext{
${ }^{32}$ See e.g. the Gospel of Philip and the Gospel of Truth, bound together with the Apocryphon of John. Cf. my further discussion in Bockmuehl 2017, 183-84 and passim.

${ }^{33}$ Exegetically less convincing is Migliasso 1979, 261 and passim (the problem of absence raised by Jesus' physical death is overcome by his perennial presence brought about in the disciples through the 'mystery' of his death). Hwang 2006 argues that it is the first Farewell Discourse itself which mediates the continuing presence of the risen Christ.
} 
The Paraclete comes from God and is sent by the Father in the name of the Son $(14.16,26)$; elsewhere he is sent by Jesus from the Father $(15.26 ; 16.13)$. He is identified as the Spirit of Truth $(14.17 ; 15.26 ; 16.13)$ or the Holy Spirit $(14.26)$ who comes to be with the disciples only after Jesus has departed $(16.7,8,13)$. Unknown to the world (14.17) but judging the world (16.8-11), he dwells in the believers and his work is to glorify Christ.

Even in the absence of Jesus, the Spirit's task and teaching is precisely what Jesus does and teaches; he speaks only what he hears (16.13). He acts to remind the disciples of Jesus, to teach them and lead them into all truth. And it is through the Spirit that Jesus is able to leave his peace with them (14.16-17, 25). By the Spirit's coming, the disciples will know that they are in Jesus and he in them; indeed, by keeping his commandments they love him and he will love them and manifest himself to them (14.20-21). The Paraclete as the 'other advocate' thus activates and makes real the abiding presence and advocacy of none other than the living Jesus, who will be with them and 'come to them' even though he is 'going away' and for a time they will not see him (14.3, 16-18, 28; cf. 20.29). ${ }^{34}$

More than in Luke, the Spirit operates as the fully empowered representative or even a kind of functional substitute for Jesus, though not as his replacement. In practice this seems to mean a substitution without radical absence: the Spirit serves as a presence of emphatically christological shape and importance, and provides a concrete focus for the continued post-Easter activity of Jesus. As Jörg Frey puts it, the work of the Spirit is to make Christ himself as well as the Father present to the Church. ${ }^{35}$

So the evidence overwhelmingly suggests that the work of the Spirit functions in terms very much like the work of Christ himself: he testifies on Christ's behalf, he convicts the world, teaches the disciples and leads them into all truth. Most importantly, perhaps, this Paraclete will mediate and represent Christ forever (14.16). Given John's view of 'the world' as predominantly a problematic place, it is particularly interesting that despite the Spirit's relationship of hostility to the world, he nevertheless operates in it, at least to convict it of $\sin$.

As we saw earlier, the question of whether the Paraclete is the same or another Advocate has long been contested. One important additional perspective on this problem is offered by the interpretation in the First Letter of John, where the Paraclete is emphatically identified as Jesus

\footnotetext{
${ }^{34}$ North 2013 links this dynamic especially to the Lazarus narrative of chapter 11, which textual and artistic sources show to have exercised a powerful influence on the early Christian imagination.

${ }^{35}$ Frey 1997-2000, 3.238.
} 
Christ the Righteous (1 John 2.1). But 1 John also confirms that the Spirit in fact mediates assurance of the abiding presence of Jesus: it is through the Spirit that we know the Son abides in those who keep his commandments (3.23-24) ${ }^{36}$ Although we will do well to exercise caution about hybrid readings of John with 1 John on this question, it does seem justifiable to read 1 John as a valid and viable first-century interpretation of the Paraclete's function in mediating and activating the presence of Jesus. In support of this reading, commentators have also rightly noted the Gospel's intimate correlation of the Paraclete with the glorified Jesus. ${ }^{37}$

In fact, a theological and Christological development in the understanding of the Paraclete has been suggested not just for 1 John. Some scholars have also suggested this within the often somewhat resumptive and circular prose of the Farewell discourses themselves: one ultimately not very persuasive account has attempted to resolve the compositional tensions of John 15-16 by reading them as a reinterpretation of chapters $13-14 .^{38}$

Despite the emphasis on the Paraclete, the Fourth Evangelist acknowledges and yet also strenuously mitigates the problem of absence. Jesus goes away, but he does so only 'for a little while' ( $\mu$ เкрóv), in order to prepare a place and swiftly to turn their pain into joy in a way that leaves no unanswered questions (16.16-22). He goes away, but that departure is never explicitly narrated, let alone in the three-dimensional terms deployed in Luke and Acts.

\section{Mystical Union with the Son}

In addition to this important Paraclete-centred resolution of Jesus' absence, 13.34-35 and 15.1-17 point to a second, ethically oriented pair of concepts that draw on an abiding and quasi-mystical union with Jesus. These twin themes of love and fruit arise from the image of the vine and its fruitbearing and from the love of Jesus for the disciples as his friends. In both cases the theme of union arguably presupposes a notion of abiding presence, perhaps along the similarly timeless-sounding lines of 14.23: 'Those who love me will keep my word, and my Father will love them, and we will

\footnotetext{
${ }^{36} \mathrm{NB}$ interpretation of the successive pronouns in 3.24 is notoriously contested. Outside John 14-16, the Gospel foregrounds a more traditional conception of the Spirit without reference to the Paraclete, but one that remains compatible (cf. 1.32-34; 3.34; 7.39; 20.22).

${ }^{37}$ E.g. Dettwiler 1995, 293-304, whom Moloney 1998, 100n53 criticizes (to my mind incorrectly) for supposedly failing to maximize the categorical theme of 'physical absence'.

${ }^{38}$ So e.g. Dettwiler 1995, 293-99 and passim. Theories of alternative versions or recensions of these discourses were liberally advocated e.g. by Brown 1979;
} 
come to them and make our home with them' (NRSV). Here it is notably Jesus himself, and not the Paraclete, who makes his home in them and the one in whom believers abide. ${ }^{39}$

It is a distinctive dimension of John's extensive treatment of our theme that so many of the key passages appear before Easter. This means that much of the discourse material develops its Christological reference to Jesus in the present tense - and as we saw earlier, there is scope for confusion about whether in addition to descending from heaven Jesus has also already ascended (e.g. $3.13)$.

One of the more intriguingly ambiguous passages attached to the Farewell Discourses themselves is the so-called High Priestly prayer of Chapter 17, whose timeless language of the Son's intercession as well as union with the Father and with his disciples makes the reader wonder where exactly the narrative camera is located. Is the point of view situated in any actual moment of the earthly life of Jesus or rather eternally in the Son's union with the Father? This ambiguity is at one level deeply rooted in John's subtle eschatology, which many Johannine scholars consider to be mostly of the realized variety (even if more clearly future-oriented in $1 \mathrm{John}$ ). ${ }^{40}$ That said, another way of describing the perspective of John 17 is in closer analogy to the experience of believers in Hebrews, where even ahead of the expected eschaton they participate in the human and angelic worship of the heavenly Mt Zion and draw near to the intercessory High Priestly ministry of Jesus. Already the intercession of Jesus is 'that they may be with me where I am, to see my glory', and indeed that 'the love with which you have loved me may be in them, and I in them' $(17.24,26)$.

\section{The Risen Jesus (20-21)}

Finally, and rather like Luke, John envisages a brief but poignant delay between Jesus' resurrection and his departure to be with the Father. During that period Jesus is still bodily present from time to time, but the nature of that presence appears complex and differently attuned to different disciples. Mary Magdalene may not touch him - but Thomas somehow needs to and is urged to do so (20.17, 27).

\footnotetext{
${ }^{39}$ This is one of a number of considerations that question the assumption of the Paraclete as a full and comprehensive substitute for Jesus, without remainder (as e.g. Dietzfelbinger 2005, 224 claims: 'vollgültiger Ersatz für den fortgegangenen Jesus').

${ }^{40}$ Cf. the discussion in Eckstein 2011, 152-55 and most fully Frey 1997-2000, both of whom also insist on retaining an element of future eschatology.
} 
Before the appearance to Thomas, Jesus bestows the Holy Spirit by breathing on the disciples - implying graphically that here, too, as Jesus departs his life-giving place is literally taken by his own pneuma (20.22).

Commentators have sometimes noted a tension between this gift of the Spirit here while Jesus is still with the disciples, and on the other hand the statement that the Paraclete cannot come unless and until Jesus departs: 'It is to your advantage that I go away, for if I do not go away, the Advocate will not come to you; but if I go, I will send him to you' (16.7). His departure is real and objective, even though the evangelist takes measures to mitigate its effects, as we saw. ${ }^{41}$

John's concluding chapter supplements the discourse about Jesus' presence in the Paraclete. It does so by juxtaposing the role of two Apostles, John and Peter. First, the possibility of the Beloved Disciple's continuing witness to Jesus until he comes; and secondly, the authorization of the restored Simon Peter as the one who will now act on Jesus' behalf in continuing the good Shepherd's care and feeding of his flock (21.15-25).

To some extent this role as the chief under-shepherd confirms for Peter the role that in traditional Catholic language has sometimes been associated with the Pope: that is, to represent Jesus as shepherd of the flock and as servant of the servants of Christ. ${ }^{42}$ This is not of course the same role as that of the Paraclete, but nevertheless it seems in certain limited respects to be analogously vicarious. The post-Easter Jesus remains the one who feeds his followers as the Bread of Life, as in Chapter 6 - and that ongoing task of nourishment is here entrusted to the rehabilitated Peter.

\section{Conclusion}

If the messianic redeemer is to be incarnate and 'God with us', then his departure and absence must inevitably raise difficulties. The Fourth Gospel at one level is most exercised by the problem of Jesus's departure and the fact that his incarnate presence has come to an end with his resurrection and ascension. In New Testament scholarship one frequently encounters claims of the post-Easter Jesus's categorical and definitive absence. One scholar's comment stands for many: 'One of the key concerns of this Gospel - perhaps even its central concern — is that of the 'absence' of Jesus for later generations. ${ }^{43}$

\footnotetext{
${ }^{41}$ See on page 19 above.

${ }^{42}$ Cf. further Bockmuehl 2012, 181-83.

${ }^{43}$ Byrne 1985, 93. Cf. also Moloney 1998, 178; and Dietzfelbinger 2005 cited above and below.
} 
In contrast to that primarily negative view, we have seen the Fourth Gospel affirm at the same time a continuing and quasi-sacramental presence of Jesus to the faith of all believers. This is quite strikingly the case in passages about Jesus as the bread of life $(6.35,48,51)$ - a promise at once rendered meaningless if Jesus is by default dead or absent. On the contrary, this abiding reality of his living presence is the necessary corollary of the claim that Jesus is life (11.25; 14.6; cf. 8.12). Similarly, one thinks of seemingly permanent promises in the Farewell Discourses about the branches abiding in the vine and vice versa (15.4) or promises as 'Those who love me will keep my word, and my Father will love them, and we will come to them and make our home with them' (14.23).

Such promises make it impossible to accept blanket statements about the categorical absence of Jesus - or about the post-Easter period as a 'time devoid of Christ', as one commentator likes to put it. ${ }^{44}$ Instead, his identity to faith in the present continues his past identity in the flesh: the Lord in whom his disciples believe is the same both before and after the Resurrection. ${ }^{45}$

The dialectic of the risen Jesus' absence and presence appears for all Four Evangelists to become more articulate and more pressing as time passes. Mark considers the question of the bridegroom's absence, but does not systematize it as a symbol of the post-Easter period. The encounter with the risen Christ and reunion with him in Galilee is essential to his understanding of the disciples' future relationship with Jesus, a point that is well appreciated by the interpretation offered by the canonical longer ending of Mark (16.19-20).

Matthew is aware of the potential challenges of Jesus's absence, but in his final chapter resolves the tension firmly in favour of the risen Lord's abiding presence in the church and in its mission of proclamation, disciple-making, baptizing and teaching. For Matthew there is no departure at all, and therefore no sustained problem of absence.

Luke is the first evangelist to deal explicitly with the end of resurrection appearances and the reality of departure; for him as for John this means that the departed Jesus sends his Spirit to continue his work. But both in the gospel and especially in Acts that same 'Lord' Jesus himself

\footnotetext{
${ }^{44}$ Dietzfelbinger 2005 speaks repeatedly of 'die christusleere Zeit' $(226,241)$ and suggests that the church requires the 'space' constituted by absence of Jesus in order to be itself and to benefit from the aid of the Spirit (225). Cf. more moderately Moloney 1998, 163, 178-79 and passim, who prioritizes the theme of faith in the physical absence of Jesus.

45 Thompson 2015 repeatedly (pp 13, 310) quotes Hoskyns 1947, 35 to good effect: 'what Jesus is to the faith of the true Christian believer, he was in the flesh.'
} 
continues in significant ways to remain the 'teaching and doing' protagonist in the apostolic mission (cf. Acts 1.1).

It is John, finally, who wrestles with the departure and absence of Jesus most explicitly of all, and develops a powerfully eschatological and sacramental vision of union with the Son as a way to assure believers of his continued presence. It is as the risen and Ascended Son that his life-giving presence through the Paraclete is at its most powerful. Perhaps the Fourth Gospel's striking realism about the tension between departure and presence is precisely what makes possible its strongly mystical and sacramental emphasis, including its strongly Christological account of the Spirit.

\section{WORKS CITED}

Anderson, Paul N. 2011. "The Origin and Development of the Johannine "egō eimi" Sayings in Cognitive-Critical Perspective." Journal for the Study of the Historical Jesus 9: 139-206.

Bauckham, Richard J. 1998. "John for Readers of Mark." In The Gospels for all Christians, 147-71. Ed. R. J. Bauckham. Grand Rapids: Eerdmans.

Bauckham, Richard J. 2007. The Testimony of the Beloved Disciple: Narrative, History, and Theology in the Gospel of John. Grand Rapids: Baker Academic.

Berger, Klaus. 1997. Im Anfang war Johannes: Datierung und Theologie des vierten Evangeliums. Stuttgart: Quell.

Bockmuehl, Markus. 2012. Simon Peter in Scripture and Memory: The New Testament Apostle in the Early Church. Grand Rapids: Baker Academic.

Bockmuehl, Markus. 2017. Ancient Apocryphal Gospels. Interpretation: Resources for the Use of Scripture in the Church. Louisville: Westminster John Knox Press.

Boismard, M. E. 2001. Comment Luc a remanié l'évangile de Jean. Cahiers de la Revue biblique 51. Paris: J. Gabalda.

Brown, Raymond E. 1966-70. The Gospel According to John. AB 29, 29A. 2 vols. New York: Doubleday.

Brown, Raymond E. 1979. The Community of the Beloved Disciple. London and New York: Chapman and Paulist.

Byrne, Brendan. 1985. "The Faith of the Beloved Disciple and the Community in John 20." Journal for the Study of the New Testament 23: 83-97.

Culpepper, R. Alan. 1999. "The Christology of the Johannine Writings." In Who Do You Say That I Am? Essays on Christology in Honor of Jack Dean Kingsbury, 66-87. Ed. M. A. Powell and D. R. Bauer. Louisville: Westminster John Knox.

Dettwiler, Andreas. 1995. Die Gegenwart des Erhöhten: Eine exegetische Studie zu den johanneischen Abschiedsreden (Joh 13,31-16,33) unter besonderer Berücksichtigung ihres Relecture-Charakters. Forschungen zur Religion und Literatur des Alten und Neuen Testaments 169. Göttingen: Vandenhoeck \& Ruprecht.

Dietzfelbinger, Christian. 2005. "Die theologische Bewältigung von Tod und Abwesenheit Jesu in den Abschiedsreden des Johannesevangeliums." Jahrbuch für biblische Theologie 19: 217-41.

Eckstein, Hans-Joachim. 2011. "Die Gegenwart des Kommenden und die Zukunft des Gegenwärtigen: Zur Eschatologie im Johannesevangelium." In Eschatologie - Eschatology: The Sixth Durham-Tübingen Research Symposium: Eschatology in Old Testament, Ancient Judaism and Early Christianity (Tübingen, September, 2009), 149-69. Ed. H.-J. Eckstein et al. Wissenschaftliche Untersuchungen zum Neuen Testament 272. Tübingen: Mohr Siebeck.

Elowsky, Joel C. 2006-07. John. Ancient Christian commentary on Scripture. New Testament. 2 vols. Downers Grove: InterVarsity Press. http://www.loc.gov/catdir/toc/ecip073/2006034855.html. 
Facius, Daniel. 2016. Ich bin: Die Selbstoffenbarung Jesu in den Bildreden des Johannesevangeliums. Bonn: Verlag für Kultur und Wissenschaft.

Förster, Hans. 2017. "Selbstoffenbarung und Identität: Zur grammatikalischen Struktur der „absoluten“ IchBin-Worte Jesu im Johannesevangelium." Zeitschrift für die neutestamentliche Wissenschaft 108: 5789.

Frey, Jörg. 1997-2000. Die Johanneische Eschatologie. Wissenschaftliche Untersuchungen zum Neuen Testament 96, 110, 117. 3 vols. Tübingen: Mohr.

Frey, Jörg. 2016. "'Wer mich sieht, der sieht den Vater": Jesus als Bild Gottes im Johannesevangelium." In Vermittelte Gegenwart: Konzeptionen der Gottespräsenz von der Zeit des Zweiten Tempels bis Anfang des 2. Jahrhunderts $n$. Chr., 179-208. Ed. A. Taschl-Erber and I. Fischer. Wissenschaftliche Untersuchungen zum Neuen Testament 367. Tübingen: Mohr Siebeck.

Gathercole, Simon. 2006. The Preexistent Son: Recovering the Christologies of Matthew, Mark, and Luke. Grand Rapids: Eerdmans.

Guardini, Romano. 1962. Johanneische Botschaft: Meditationen über Worte aus den Abschiedsreden und dem Ersten Johannes-Brief. [1. Aufl.]. Würzburg: Werkbund-Verlag.

Henry, Michel. 2003. I am the Truth: Toward a Philosophy of Christianity. Trans. S. Emanuel. Stanford: Stanford University Press.

Hill, Charles E. 2004. The Johannine Corpus in the Early Church. Oxford etc.: Oxford University Press.

Hofrichter, P. L., ed. 2002. Für und wider die Priorität des Johannesevangeliums. Hildesheim: Olms.

Hoskyns, Edwyn Clement. 1947. The Fourth Gospel. Ed. F. N. Davey. Rev. edn. London: Faber and Faber.

Hwang, Won-Ha. 2006. The Presence of the Risen Jesus in and Among His Followers With Special Reference to the First Farewell Discourse in John 13:31-14:31. PhD. Dissertation, University of Pretoria.

Käsemann, Ernst. 1969. "The Structure and Purpose of the Prologue to John's Gospel." In New Testament Questions of Today, 138-67. London: SCM.

Kobel, Esther. 2011. Dining with John: Communal Meals and Identity Formation in the Fourth Gospel and its Historical and Cultural Context. Leiden: Brill.

Koester, Craig R. 2003. Symbolism in the Fourth Gospel: Meaning, Mystery, Community. 2nd edn. Minneapolis: Fortress Press.

Lindars, Barnabas. 1992. "Rebuking the Spirit: A New Analysis of the Lazarus Story of John 11." New Testament Studies 38: 89-104.

Matson, Mark A. 2001. In Dialogue with Another Gospel?: The Influence of the Fourth Gospel on the Passion Narrative of the Gospel of Luke. SBL Dissertation Series 178. Atlanta: Society of Biblical Literature.

Matson, Mark A. 2004. "Current Approaches to the Priority of John." Stone-Campbell Journal 7: 73-100.

Meeks, Wayne A. 1972. "The Man from Heaven in Johannine Sectarianism." Journal of Biblical Literature 91: 44-72.

Metzger, Bruce Manning. 1994. A Textual Commentary on the Greek New Testament. 2nd edn. New York: American Bible Society.

Migliasso, Secondo. 1979. La presenza dell'Assente: saggio di analisi letterario-strutturale e di sintesi teologica di Gv. 13,31-14,31. Ph.D. dissertation, Pontifical Gregorian University.

Moloney, Francis J. 1998. Glory not Dishonor: Reading John 13 - 21. Minneapolis: Fortress.

Morgan, Robert. 1996. "Can the Critical Study of Scripture Provide a Doctrinal Norm?" Journal of Religion 76: 206-32.

Nielsen, Jesper Tang. 2018. "Johannes und Lukas." In Rewriting and Reception in and of the Bible, 125-62. Ed. J. Høgenhaven et al. Wissenschaftliche Untersuchungen zum Neuen Testament 396. Tübingen: Mohr Siebeck.

North, Wendy E. Sproston. 2013. "'Lord, if you had been here ...' (John 11.21): The Absence of Jesus and Strategies of Consolation in the Fourth Gospel." Journal for the Study of the New Testament 36: 3952.

Otto, Rudolf. 1923. The Idea of the Holy: An Inquiry into the Non-Rational Factor in the Idea of the Divine and its Relation to the Rational. Trans. J. W. Harvey. London: Oxford University Press. 
Petersen, Silke. 2008. Brot, Licht und Weinstock : intertextuelle analysen johanneischer Ich-bin-Worte. Supplements to Novum Testamentum, 127. Leiden ; Boston: Brill.

Popkes, Enno Edzard. 2017. "Die verborgene Gegenwärtigkeit Jesu: Bezüge zu eucharistischen Traditionen in Lk 24 und den johanneischen Schriften." In The Eucharist - Its Origins and Contexts: Sacred Meal, Communal Meal, Table Fellowship in Late Antiquity, Early Judaism, and Early Christianity, 1:503-12. Ed. D. Hellholm and D. Sänger. Wissenschaftliche Untersuchungen zum Neuen Testament 1:376. Tübingen: Mohr Siebeck.

Robinson, John A. T. 1985. The Priority of John. London: SCM.

Rusam, Dietrich. 2005. "Das Johannesevangelium - eine "Relecture" der synoptischen Evangelien? : Intertextuelle Beobachtungen zu den "Ich-bin-Worten" des Johannesevangeliums." In Kultur, Politik, Religion, Sprache - Text: Wolfgang Stegemann zum 60. Geburtstag, 377-89. Ed. C. Strecker. Stuttgart: Kohlhammer.

Schnelle, Udo. 1992. Antidocetic Christology in the Gospel of John: An Investigation of the Place of the Fourth Gospel in the Johannine School. Trans. L. M. Maloney. Minneapolis: Fortress Press.

Shellard, B. 2002. New Light on Luke: Its Purpose, Sources and Literary Context. Journal for the Study of the New Testament: Supplement Series 215. Sheffield:: Sheffield Academic Press.

Slenczka, Notger. 1993. Realpräsenz und Ontologie: Untersuchung der ontologischen Grundlagen der Transsignifikationslehre. Göttingen: Vandenhoeck \& Ruprecht.

Thompson, Marianne Meye. 1988. The Humanity of Jesus in the Fourth Gospel. Philadelphia: Fortress.

Thompson, Marianne Meye. 2015. John: A Commentary. The New Testament Library. Louisville: Westminster John Knox Press.

Walsh, David. 2015. Politics of the Person as the Politics of Being. Notre Dame, IN: University of Notre Dame Press.

Whitacre, Rodney A. 1999. John. Downers Grove, III. ; Leicester: InterVarsity Press.

Williams, Catrin H. 2000. I am He: The Interpretation of 'Anî Hû' in Jewish and Early Christian Literature. Wissenschaftliche Untersuchungen zum Neuen Testament 2:113. Tübingen: Mohr Siebeck.

Witherington, Ben. 1995. John's Wisdom: A Commentary on the Fourth Gospel. Louisville: Westminster John Knox Press. 